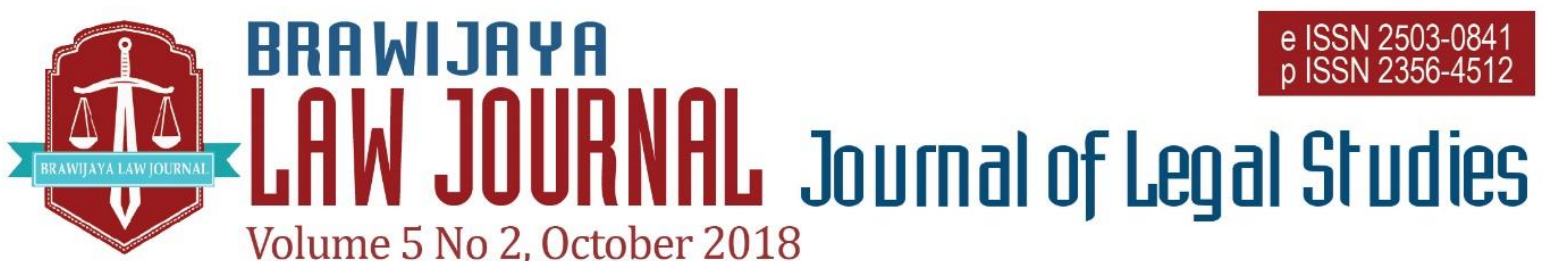

Volume 5 No 2, October 2018

Nationally Accredited No. 32a/E/KPT/2017 Dated 26th April 2017

This work is licensed under a Creative Commons Attribution-NonCommercial 4.0 International License

\title{
Conflict in Management of Passive State Administrative Decision in State Administrative Dispute
}

\author{
Agustien Cherly Wereh ${ }^{1}$, Istislam ${ }^{2}$ \\ ${ }^{1}$ Faculty of Social Science Universitas Negeri Manado \\ Email: mdo.lulu@yahoo.co.id \\ ${ }^{2}$ Faculty of Law, Brawijaya University \\ Email: istislam@ub.ac.id
}

Submitted : 2018-10-05 | Accepted : 2018-10-22

\begin{abstract}
The government's task to achieve the state's objective is provided in the preamble of the 1945 Constitution of the Republic of Indonesia. In the governance system, societies often encounter tough situation, while administrative law has specially actualised constitutional norms of correlation between the state and its societies. The administrative management in the Law is seen as essential instrument of a democratic state of law, in which decision and/or act is determined by an entity and/or a government official or government apparatus involving executive, judicative, and legislative entities that run governmental functions which are possible to be examined at court.

The research problem presented in this research is why there are differences between positive-passive system (stelsel) and negative-passive system regarding the management of state administrative decision. This research employed normative legal research along with prescriptive analysis method. The research result indicates that the emergence of conflict in passive administrative state management is caused by the inaccuracy of legislation in formulating laws.
\end{abstract}

Keywords: conflict, passive state administrative decision, administrative disputes, state administrative court, judicature

\section{INTRODUCTION}

According to the provision of Article 1 Paragraph (2) of the 1945 Constitution of the Republic of Indonesia of 1945, the sovereignty is held by people and implemented in compliance with the Constitution, and Article 1 paragraph (3) of the 1945 Constitution of the Republic of Indonesia asserts that Indonesia is a state of law. It indicates that the governance of the
Republic of Indonesia shall be based on the principles of sovereignty of the people and the state of law. Therefore, all forms of decisions and/or any administrative acts of government shall comply with the sovereignty of the people and law reflecting Pancasila as the ideology of the state, not comply with the power attached to the position of government officials. 
The decisions and or acts toward people must be in line with the provisions of legislation and general principles of good governance (further stated as AUPB). ${ }^{1}$ Monitoring on the decision and/or act is a form of a test to see whether citizens concerned are treated according to the existing law and should be in line with the principles of legal protection that can be effectively performed by state bodies and state administrative court (further stated as PTUN) that is known independent. Therefore, systems and procedures regulating the implementation of government administrative tasks and development must be regulated in law.

Administrative Laws (hereinafter referred as UUAP) principally actualises the constitutional norms of the correlation between the state and its people. The management of government administration in the law is an important instrument of democratic state of law, in which decisions and/or acts are determined by government bodies and/or officials or state apparatuses involving executive, judicative, and legislative bodies that run governmental functions that enable investigation at court. All of those form ideal values of a state of law.

The management of government administration guarantees that decisions and/or acts of government bodies and/or officials to the people cannot be made or performed arbitrarily. The law will not easily allow people to accidentally become the victim of the state power. ${ }^{2}$ Moreover, the law is also known as a transformed AUPB that has been implemented for years in the governance, concreted into binding law.

\footnotetext{
1 Titik Triwulan Tutik, 'Analisis Hukum Tata Negara', (2015) Jurnal Hukum dan Pembangunan 411,20
}

The management of government administration is principally a measure to build main principles, ideas, behaviours, cultures, and democratic, objective, and professional administrative acts to achieve justice and legal certainty. This law is a set of measures to re-manage the decisions and/or acts of government bodies and/or officials according to the provisions of legislation and AUPB. The law is intended not only to serve as a legal protection for government apparatuses but also as instrument to improve the quality of government services to public. Thus, the existence of the law could create good governance for all government bodies or officials in both regional and central areas.

In the governance process, societies often encounter demanding bureaucracy, limited state apparatuses, lack of professionalism of government officials, inaccuracy caused by the officials, bribery, and so forth, all of which are considered as disobedience of the apparatuses to AUPB.

All those problems trigger the consideration of making UUAP. Interestingly, it is stated in Article 53 of UUAP that:

1. The deadline given to determine and/or make decisions and/or acts complies with the provisions of legislation.

2. If the provisions of legislation does not set the deadline of the responsibility as meant in Paragraph (1), government bodies and/or officials must determine and/or make decisions and/or perform acts no later than 10 (ten) working days after a lawsuit is completely submitted to the government bodies and/or officials.

3. If a government body and/or an official has not determined and /or make a

\footnotetext{
2 Abu Tamrin, 'Perubahan Konstitusi dan Reformasi Ketatanegaraan Indonesia' (2015) Jurnal Cita Hukum 3 1, 16
} 
decision and/or perform any act based on the deadline as mentioned in Paragraph (2), the lawsuit is granted lawfully.

4. The claimant submits a lawsuit to court to hear a decision regarding the accepted lawsuit as mentioned in Paragraph (3).

5. Court is obligated to decide a proposal as mentioned in Paragraph (4) no later than 21 (twenty one) working days since the proposal is submitted.

6. A government body and/or official must determine a decision in order to execute court decision as mentioned in Paragraph (5) no later than 5 (five) working days since court decision is released.

Article 53 Paragraph (3) of UUAP states that: If, within 10 days, a government body and/or an official does not determine and/ or make a decision and/or does not act, the proposal is lawfully granted. In other words, the public merely needs to look forward to the decision accepted by PTUN.

What is mentioned earlier is contrary to Article 3 Paragraph (2) of Law Number 5 of 1986 on State Administrative Court, (LNRI of 1986 Number 77), (further stated as UU PTUN), stating: if a state administrative body or official does not stipulate a decision that is proposed and the stipulation of the data of the legislation is past the deadline, it is concluded that a state administrative body or official has rejected to release the decision.

This is supported by Article 15 sub (c) of the Regulation of Supreme Court (Perma) No. 5 of 2015 on Litigation Guidelines to obtain Decision regarding the acceptance of lawsuit proposal to obtain Decision and/or

3 Djoko Prakoso, Peradilan Tata Usaha Negara, (Yogyakarta: Liberty, 1988), p. 58 act of a government body and/or official, stating:

(c). "stating that the lawsuit is rejected, as it does not hold any legal reason."

Thus, it is concluded there is dualism of law in the management of State Administrative Decision, but PTUN will inspect and adjudicate the lawsuit submitted. This is due to the fact that the establishment of state administrative court can be seen as a tendency of the government to protect human rights of the state from the power of the government in the governance. ${ }^{3}$ The effectiveness of UU PTUN is under the bless of Allah the Almighty and is supported by a core intention of Indonesia to realise the state of law that is based on the 1945 Constitution of the Republic of Indonesia and Pancasila. In an effort to achieve fair and prosperous life as intended by Indonesia, the government has played an active role in societies. In such a condition, the position of the citizens in the state is guaranteed lawfully. However, in the implementation, all functions to guarantee the equality in law for the people should also be relevant to the perspective and characteristic of the state according to Pancasila to achieve uniformity, balance, and harmony between individual interests and common interests in a country development. ${ }^{4}$ There is a juridical problem to discuss regarding the above provisions.

\section{LEGAL RESEARCH AND METHOD}

This is a normative legal research, which is aimed to study regulations, legal concepts as well as legal principles behind the discovery of legal principles towards written and unwritten positive law, in which

\footnotetext{
4 Martiman Prodjohamidjojo, Hukum Acara Pengadilan Tata Usaha negara \& UU PTUN 2004, (Bogor: Ghalia Indonesia, 2005), p. 1
} 
the written positive law refers to legislation such as UUAP and UU PTUN. This research is focused more on statute, conceptual, case, and comparative approaches, while the legal materials obtained were studied prescriptively to generate details regarding the essence of legal research that holds on to the characters of a legal study as an applied science.

\section{RESULTS AND DISCUSSIONS}

\section{Law of the Republic of Indonesia No. 5 of} 1986 on State Administrative Court, Law No. 9 of 2004 on Amendment of Law of the Republic of Indonesia No. 5 of 1986 on State Administrative Court.

The constitution of Indonesia states that Indonesia is a state of law ${ }^{5}$ not based on merely power. An indicator of a state of law is reflected from the existence of four domains of judicatures in Indonesia as mentioned in Article 10 of Law No. 14 of 1970 Jo. Law No. 39 of 1999, which was then amended to Law No. 4 of 2004, the four of which are stated as follows:

1. Domain of General Judicature with law No. 2 of 1986 (LN RI of 1986 No. 20) jo. Law No. 8 of 2004 (LN RI of 2004 No. 34) jo. Law No. 49 of 2009 (LN RI of 2009 No. 158).

2. Domain of Religious Judicature with Law No. 7 of 1987 (LN RI of 1989 No. 49) jo. Law No. 3 of 2006 (LN RI of 2006 No. 22) jo. Law No. 50 of 2009 (LN RI of 2009 No. 159)

3. Domain of Military Judicature with Law No. 31 of 1997 (LNN RI of 1997 No. 84)

5 The 1945 Constitution of The Republic of Indonesia, Article 1 Paragraph (3), UUD'45 dan Amandemennya, (Surakarta; Pustaka Mandiri, 2014), p. 11

6 Point a considering, Law Number 5 of 1986 on State Administrative Judicature, (Bandung: Fokusmedia, 2014), p. 93
4. Domain of State Administrative Judicature with Law No. 5 of 1986 (LN RI of 1986 No. 77) jo. Law No. 9 of 2004 (LN RI o 2004 No. 35) jo. Law No. 51 of 2009 (LN RI of 2009 No. 160).

State Administrative Court (PTUN), the last judicature to form, was marked with the validation of the Law of State Administrative Judicature on December 29, 1986 in the preamble 'considering', in which it is mentioned that the intention of the formation of PTUN is to realise secure, safe, welfare, and obedient state governance that guarantees the status of its citizens in law and maintain harmonised and balanced relationship between state administrative apparatuses and societies. ${ }^{6}$

Actively performing its tasks, the government should not violate any rights and obligations of its citizens. Moreover, the balance between state interests or state administrative interests ${ }^{7}$ and individual interests should be maintained. Protection is provided by PTUN which holds equal proportion as General, Religious, and Military Courts that are free from any influence or power, meaning that to prevent any criminal acts by any authorised bodies, PTUN serves as a law stabiliser to run its function as a law instrumentality ${ }^{8}$ in addition to its responsibility to maintain order and its function as a shelter of justice. Law of PTUN started to function effectively on January 14, 1991 according to Government Regulation Number 7 of 1991, marked by inauguration of the three State Administrative High Courts (PTTUN) in Jakarta, Medan, and Ujung

7 A speech by Minister of Justice in State Administrative Judicature Symposium, printed on BPHN Publication (Bandung: Binacipta, 1977), p. 22-23

${ }^{8}$ Sunaryati Hartono, Peranan Peradilan Dalam Rangka Pembinaan dan Pembaharuan Hukum Nasional, (Bandung: Binacipta, 1975), P. 8 
Pandang, and five State Administrative Courts (PTUN) in Jakarta, Medan, Palembang, Surabaya, and Ujung Pandang, followed by the establishment of PTUNs in all the capitals of provinces as level one courts. To date, the existence of State Administrative Courts which are authorised to investigate, decide, and adjudicate any state administrative dispute between government (executives) and its people is perceived to have not been optimally performed in giving protection to the people and in providing healthy and law-abiding apparatuses who are aware of their tasks and function as public servants and protectors of the societies.

In Law No. 4 of 2004 on Amendment of Law No. 14 of 1970 jo. Law No. 35 of 1999 on Principles of Judicial Power explicitly suggests in Article 11 that:

"(1) judicial bodies as mentioned in Article 10 Paragraph (1), in organisation, administrative, and financial perspective are under the power of Supreme Court"

(2) "Provision regarding organisation, administration, and finance is referred to as in each judicature domain".

Based on the above provision, legislation that regulates judicial bodies in Indonesia including the domain of PTUN with regard to Law No. 5 of 1986 must be amended, as in organisation, administrative, and financial perspectives, as the judicial bodies are still under the Department of Justice, as regulated in Article 7 Paragraph (2) and Article 13 Paragraph (1) on General Monitoring and Fostering. Juridically, the amendment of Law Number 5 of 1986 is a command addressed to legislators to fulfil what is suggested in Law No. 35 of 1999, meaning that it is imperatively ordered by Law Number 35 of 1999, as normatively the existence of law No. 5 of 1986 is not in line with the provision of Article 11 of Law No. 35 of 1999 as the main law.

In line with the mechanism of law making, the government through the Department of Justice and Human Rights has proposed a bill in regard to amendment of law of PTUN, and it is now regulated in Law No. 9 of 2004 and is amended to Law No. 51 of 2009. Philosophically, the amendment of Law No. 5 of 1986 is aimed to foster an independent court not influenced by external authorities and other parties. This is in line with the provision of People's Consultative Assembly No. IV/MPR/1999 on State Policy Guidelines. The existing law instrumentalities have overlooked philosophical values stemming from independent judicial power because the law is used to maintain power. This perspective is relevant to Karl Mark's notion (as cited by Soerjono Soekamto): ${ }^{9}$

"Law is a tool used by those holding power to maintain their power", including rules regulating judicial power which theoretically is a power delegated to the executor of judicial power called judges to perform their tasks and run their functions as justice providers for the people without any interference from other parties. It means the decision is independently made by judges in court."

In law No. 9 of 2004 on Amendment of Law No. 5 of 1986 has completely abolished the interference from the government and supported the independence of judges that are

\footnotetext{
9 Seorjono Soekamto, Penegakan Hukum, (Bandung: Bina Cipta, 1985), p. 15
} 
free from influence of other parties. ${ }^{10}$ Seen from the substance, Law No. 9 of 2004 on Amendment of law No. 5 of 1986, measure to impose sanctions regarding conducts done by government who fails to comply with the Decision of State Administrative court is obvious. This is indicated by the fact regarding the execution of decision of PTUN, which is seen insufficient due to non-real execution. These days, the execution is more concrete, and sanctions imposed on state administrative bodies or officials failing to comply with the decision or regulation are possible. The sanctions can be given in the form of recognisance and administrative sanction ${ }^{11}$ and they have to be announced on local newspaper (Article 116 Paragraph (4) ${ }^{12}$ and (5)). ${ }^{13}$

The above explanation indicates that there are measures to improve and maintain the image and existence of PTUN, which has been apathetic in obtaining justice from State Administrative court. Moreover, it is expected that the amendment of fundamental Articles in Law No. 9 of 2004 will represent the intention and objective of the PTUN: it is expected to foster law-abiding apparatuses for more optimal services and protection provided for societies. Social political changes in post-reformation affects the measures taken by law instrumentalities that

\footnotetext{
${ }^{10}$ Article 7 Paragraph (1) and (2) of Law Number 9 of 2004: Paragraph (1) Fostering judicature techniques, organisation, administration, and judicature financial by Supreme Court, Paragraph (2) fostering as meant in Paragraph (1) should not reduce the independence of judges in investigating and handling State Administrative disputes.

11 Istislam, Sanksi Paksaan Pemerintah dalam Perlindungan dan Pengelolaan Lingkungan Hidup, dissertation, 2012, p. 25-26

12 Article 116 Paragraph (4) of Law Number 9 of 2004: the defendant is not willing to act as what has been decided by the Court that holds permanent legal force. Administrative sanctions or recognisance must be imposed on the officials concerned.
}

intend to transform law into supremacy of the law.

In terms of law No. 9 of 2004 on Amendment of Law No. 5 of 1986 on State Administrative Judicature, this is the implementation and reformation demand in law in which it aims to transform State Administrative Judicature Bodies into one of instruments to enforce law for government apparatuses. In line with the objective of the establishment of the State Administrative Judicature, there have been some measures taken regarding the establishment in earlier years in the beginning of independence, ${ }^{14}$ while the political will of new government started to exist in the mid 1980s, which was marked by the validation of Law No. 5 of 1986. It is because the existence of the bodies of State Administrative Judicature affects the policies that have been or will be implemented by the government, recalling that the Decision of State Administration issued by the government becomes the object of dispute. ${ }^{15}$

Theoretically, as a state, the existence of Indonesia stems from its people's will to unite (Le desire d'etre ensemble. Sudarsono ${ }^{16}$ further stated that there are at least 5 (five) requirements that characterise a state:

1. Constitutional-based government

2. Legality principles

13 Article 116 Paragraph (5) of Law Number 9 of 2004: Officials who do not act in accordance with what has been decided in court as mentioned in Paragraph (4), their names are to be announced publicly on local printed media by court clerks since the provision is fulfilled as mentioned in Paragraph (3).

14 See the formation history p. 55-76

15 Sudarsono, Pilihan Hukum Dalam Penyelesaian Sengketa Tata Usaha Negara di Peradilan Tata Usaha Negara, Professorship Inaugural Speech of State Administrative Law of Faculty of Law Universitas Brawijaya, (Malang: 2008), p.18

16 Ibid. 
3. Separation of power in government functions

4. Independent judicial power

5. Guarantee of protection of Human Rights

Indonesia as a state of law with the above characteristics should hold the process of democracy, in which its people should be accommodated to be involved in decisionmaking, especially in occasions that determine their welfare. Therefore, it is expected that the supremacy of the law formed in a democratic state of law can function as the law that serves its people.

Furthermore, it is essential to see to what extent the existence of Law No. 5 of 1986 and the amendment to Law No. 9 of 2004 is when related to political configuration referred to by Indonesia.

When the substance of Law No. 5 of 1986 and Law No. 9 of 2004, the author opines that since it is based on Indonesia as a democratic state which is not authoritarian, law No. 5 of 1986, especially the amendment to Law No. 9 of 2004, is responsive. Specifically, the objective of the establishment of State Administrative Judicature with law no. 5 of 1986 as its law instrumentality, which was then amended to Law No. 9 of 2004, indicates that Indonesia is a democratic state of law. In short, Law No. 5 of 1986 on State Administrative Court (PTUN) validated on December 29, 1986 (LN. 1 986/Number 77, TLN Number 3344), which is also recognised as State Administrative Judicature, is an indicator of the principle suggesting that Indonesia is a state of law as intended by the 1945 Constitution of the Republic of Indonesia.

17 H.Lutfi Effendi, Hukum Acara Peradilan Tata Usaha Negara, (Malang: Bayumedia Publishing, 2010) p. 4
The essence of PTUN is perceived by the people of Indonesia who demand security and justice among them regarding the growing interference of the government in almost all aspects of life, leading to more intensive use of regulatory and management instruments for societies, which sparks conflict of interests between the government and its people.

What matters in judicature is the imbalanced position between judicatures and justice seekers in which the government (which governs) becomes a defendant and, on the other hand, people (the governed) become the plaintiffs. Neutraliser is required to fix the imbalance between the government and its people to settle disputes. Thus, the role of judges in judicature is determining to settle disputes and seek objective righteousness. ${ }^{17}$

Negative passive system decision is a decision which should be produced by state administrative judicature but nonetheless such decision was never proclaimed. The implementation of negative passive system by Law of State Administrative Court follows the consideration in which State Administrative Judicature is a new body in Indonesia. To avoid any conflict, the former Minister of Justice, Ismail Saleh, S.H., suggested that limited authority should be provided, in which it should be restricted to only adjudicate all concrete, individual, and final decisions made by State Administrative officials (vide Law No. 5 of 1986). ${ }^{18}$

\section{Law of the Republic of Indonesia No. 30 of 2014 on Government Administration}

The basis of principles in legislation involves philosophical principle,

18 Naskah akademik tahun 1981, prepared by Badan Pembinaan Hukum Nasional (BPHN) Department of Justice, under supervision of Chairman Chaerani AS Gani,S.H. 
sociological principle, and juridical principle, three of which should be clearly defined in the preamble and in general explanation.

The main description that serves as the basis of the making of Law No. 30 of 2014 is as follows:

\section{Philosophical aspect}

Philosophically, Law Number 30 of 2014 on Government Administration describes the principles of the system of the implementation of the government of the Republic of Indonesia which is based on the following:

1. The principle of the sovereignty of people and the principle of the state of law (rechsstaat). According to those two principles, all forms of decisions and/or acts of government administration should be based on the sovereignty of people and law which are the reflection of the Pancasila as an ideology of the state. Thus, all decisions and/or acts are not according to the power attached to position of governments (machtsstaat).

2. Decisions and/or acts made or done by government bodies and/or officials to the people should be in accordance with the provisions of legislation and general principles of good governance (rechtmatigheid van bestuur). ${ }^{19}$

3. Monitoring of decisions and/or acts to see whether people are treated according to the law can be performed by state bodies and State Administrative Court.

4. The Law of Government Administration guarantees basic rights and provides protection to societies and guarantees the execution of state's tasks.
5. This Law enables people to propose appeal to higher court regarding the decisions and/or acts to government bodies and/or officials or the directors of the officials concerned. Societies could also file a lawsuit regarding the decisions and/or acts done by government bodies and/or officials to State Administrative Court.

The principle serves as a guideline to state administrative dispute settlement through stages of administrative measures to judicature body.

As referred to the sociological principle, although Law Number 30 of 2014 on Government Administration uses the term "is able to propose some administrative measures", this term should not be taken as a choice but it is an obligation.

6. The scope of management of decisions and/or acts made and/or done by government bodies and/or officials or other state apparatuses comprises bodies other than executives, judicative, and legislatives that run the state, which is possible to be investigated at court.

\section{Sociological Aspect}

Systematic description regarding the sociological aspect that serves as the background of the issuance of Law Number 30 of 2014 on Government Administration elaborates the principles in the system of the governance of the Republic of Indonesia in accordance with:

1. Guaranteeing the people as subjects (not as objects) in a state of law.

2. Guaranteeing the people regarding the fact that decisions and/or acts by

19 Evi Purnama Wati, 'Sumber-Sumber Hukum Tata Negara Indonesia', (2015) Jurnal Hukum Universitas Palembang 93, 11 
government bodies and/or officials cannot be done to people arbitrarily.

\section{Juridical aspect}

Systematic description regarding juridical aspect that serves as the background of the issuance of Law Number 30 of 2014 on Government Administration elaborates the principles in a system of governance of the Republic of Indonesia according to:

1. Law Number 30 of 2014 on Government Administration transforms and provides norms in General Principles of Good Governance (AUPB) that has been put into practice. These general principles develop in line with the dynamic of the societies living in a state of law.

2. Law Number 30 of 2014 on Government Administration lays the groundwork for governance to bring it to good governance and as measure to prevent corruption, collusion, and nepotism practices.

3. Law Number 30 of 2014 on Government Administration as a measure to develop main principles, way of thinking, behaviour, culture, and democratic, objective, and professional administrative actions to bring justice and legal certainty in. ${ }^{20}$

4. Law Number 30 of 2014 on Government Administration completely re-regulate decisions and/or actions done by government bodies and/or officials according to the provisions of legislation and General Principles of Good Governance (AUPB).

5. Law Number 30 of 2014 on Government Administration is not only restricted to providing legal protection for government apparatuses, but it is an instrument to improve the quality of government services to public. This law is expected to create good governance for all government bodies and/or officials both in central and regional areas.

According to Article 1 Paragraph (3) of the 1945 Constitution of the Republic of Indonesia, Indonesia is a state of law, meaning that the governance system of Indonesia must be based on the sovereignty of the people and the principles of the state of law.

The logical consequence is that, in line with all those principles, all decisions and/or actions by government administration must be based on the sovereignty of the people and law that serve as a reflection of Pancasila as the state's ideology. Acts done by government administration not affected by authority attached to the state position are not unconditional. The public should not be treated as objects arbitrarily.

A question is raised regarding what administrative measures are taken by government administration? The decisions and/or acts to the public must comply with the provisions of legislation and General Principles of Good Governance (AUPB). This certainly requires supervision on the decisions and /or acts to see whether the public is treated in accordance with the law and has to pay attention to the principles of legal protection which can effectively be performed by state bodies and State Administrative Court which is independent and unaffected. The system and procedure required in the execution of government's tasks and development must be regulated in law.

20 Despen Heryansyah, 'Pergeseran Kompetensi Absolut PTUN dalam sistem Hukum Indonesia' (2017) 81 Jurnal Hukum Novelty, 5 
In the perspective of construction of law, Law Number 30 of 2014 constitutes material law of the state administrative law. This enables public to possibly file a lawsuit regarding the decisions and/or acts done by government bodies and/or officials to State Administrative Court, for this law is a material law that comes from the system of State Administrative Court.

Constitutionally, the existence of Law of Government Administration is a specific actualisation of constitutional norms between the state and its people.

From the perspective of state administrative law, the management of government administration in the Law is an essential instrument of a democratic state of law, in which the decisions and/or acts made and/or done by government bodies and/or officials or by other government apparatuses other than executives, judicative, and legislative that run the governmental functions are to be adjudicated in court.

The existence of Law Number 30 of 2014 is principally an implementation of ideal values of a state of law, meaning that the execution of state's authority should be pro-public, recalling that this law exists to guarantee the people as subjects in a state of law as to prioritise the sovereignty of people.

Basic consideration of the issuance of Law Number 30 of 2014 involves the following three:

1. To improve the quality of the governance, government bodies and/or officials must refer to the general principles of good governance and the provisions of legislation in order to use the authority.

21 Article 5 of Law of Government Administration: Government tasks are based on: a. legality principle, b. principle of protection of human rights, c. AUPB
2. To settle dispute in the governance, the regulation regarding government administration is expected to serve as a solution in providing legal protection for both the public and government officials.

3. To realise good governance, especially for the government officials, the law of government administration serves as the legal basis required to create a fundamental for the decisions and/or acts done by the government officials to fulfil what is needed by law that regulates the governance.

The legality principles ${ }^{21}$ in the state administration binds administrative decisions from legislative power and becomes the subject of monitoring of judicative power, ${ }^{22}$ meaning that there is no such an administrative decision without any legal foundation from legislatives and without any legal monitoring from judicative. This principle comprises two elements in which administrative decisions must comply with Law and must not be against the Law. All administrative activities are principally authorised by Law. The government has no authority to order or prohibit its people but with the authority given by the Law. However, there still has to be discretion for the government to give public services. The Law only contains general provisions that need elaborating in the lower Legislation. Thus, the government is allowed to use the discretionary power under the law. The discretionary power should not be separated from the main legal framework, or the power and the authority will be violated.

Another basic principle is related to the principle of supremacy, in which the

22 Academic Articles of Law Number 30 of 2014 on Government Administration, p. 13-14 
government either as state administration executor or judicative power must comply with legislative power. The government is not allowed to violate the regulation in Law although it does not cause any harm to its people. Law is no restricted to as government's framework, but the acts of the government are also reflected by the law. The second element of legality principle is that all acts done by the government must be done in accordance with legal foundation, in the form of legal framework, presidential decree, or the decision of regional head or of government official. This element demands the formal decisions made by the government that is lawfully binding.

The governments' acts are classified into two categories: facts of the case and legal consequences. ${ }^{23}$ When the facts of the case are fulfilled, the legal consequences follow. It clarifies that the acts done by the government are called administrative acts when they are related to the facts of the case, while they have something to do with legal consequences, they are categorised as acts of discretion. The examination on the government's acts by judicative bodies can only be performed toward control legality (Rechtmaessigkeit), not towards the conformity of objective (Zweckmaessigkeit).

The reasons of UUAP to follow the positive passive system are clearly seen in the objective of the formation of the Law:

1. to create order in Government Administration

2. to provide legal protection

3. to prevent the possibility of authority abuse

4. to guarantee accountability of government bodies and/or officials

23 Pan Mohammad Faiz, 'Perlindungan terhadap Lingkungan dalam Perspektif Konstitusi', (2016) 1304 Jurnal Konstitusi
5. to provide legal protection for the people and government apparatuses

6. to execute the provisions of legislation and the implementation of AUPB

7. to provide the best services for public

\section{CONSLUSIONS AND SUGGESTIONS}

The differences between positivepassive system (stelsel) and negative-passive system regarding the management of state administrative decision exist due to the inaccuracy of formulation of law by the Legislatives. This is shown by the existing conflict of norms between Article 53 paragraph 3 of Law Number 30 of 2014 on Government Administration and to Article 3 Paragraph (2) of Law Number 5 of 1986 on PTUN. In Article 53 Paragraph (3), it is stated that when government bodies and/or officials do not make any decision and/or take any action within 10 days, the proposal is lawfully granted. In other words, the public is only required to wait the decision of State Administrative Court (PTUN) to be accepted. This condition is contradictory to Article 3 Paragraph (2) of Law Number 5 of 1986 on PTUN, implying that when State Administrative bodies or officials do not release any decisions proposed and it is past the deadline, it means that the state administrative bodies or officials reject to issue decisions. It is advisable that Law Number 30 of 2014 on Government Administration serves as material law from the system of PTUN, not to interfere with the domain of PTUN which is under the Supreme Court that holds independent judicial power to enforce law and justice. 


\section{REFERENCES}

\section{Books}

Djoko Prakoso, Peradilan Tata Usaha Negara, (Yogyakarta: Liberty, 1988) H.Lutfi Effendi, Hukum Acara Peradilan

Tata Usaha Negara, (Malang:

Bayumedia Publishing, 2010)

Martiman Prodjohamidjojo, Hukum Acara

Pengadilan Tata Usaha Negara \& UU

PTUN 2004, (Bogor : Ghalia

Indonesia, 2005)

Sunaryati Hartono, Peranan Peradilan

Dalam Rangka Pembinaan dan

Pembaharuan Hukum Nasional,

(Bandung: Binacipta, 1975)

Seorjono Soekamto, Penegakan Hukum,

(Bandung: Bina Cipta,1985)

Pidato Pengarahan Menteri Kehakiman pada Simposium Peradilan Tata Usaha Negara dimuat dalam terbitan BPHN (Bandung: Binacipta, 1977)

\section{Journal Articles}

Ackerman, B.A and Steward, R.B., Reforming Environmental Law: The Democratic Case for Market Incentive, Colombia Jurnal of Environmental Law (1998) 13

Heryansyah, Despen 'Pergeseran

Kompetensi Absolut PTUN dalam sistem Hukum Indonesia' (2017) 81

Jurnal Hukum Novelty, 5

Tamrin, Abu 'Perubahan Konstitusi dan Reformasi Ketatanegaraan Indonesia' (2015) Jurnal Cita Hukum 31

Tutik, Titik Triwulan 'Analisis Hukum Tata Negara', (2015) Jurnal Hukum dan Pembangunan 41 1, 20

Wu Jin, song, Analyses on The Function of Administrative Law Enforcement Intepretation in China, Canadian Social Science (2010) 62.
Faiz, Pan Mohammad, 'Perlindungan terhadap Lingkungan dalam Perspektif Konstitusi', (2016) 1304 Jurnal Konstitusi

\section{Thesis}

Istislam, Sanksi Paksaan Pemerintah Dalam Perlindungan Dan Pengelolaan Lingkungan Hidup, Disertasi, 2012

\section{Acts}

Undang-undang Dasar Republik Indonesia Tahun 1945 Pasal 1 ayat (3), UUD'45 DAN AMANDEMENNYA, (Surakarta; Pustaka Mandiri, 2014)

Undang-Undang No. 5 Tahun 1986 tentang Peradilan Tata Usaha Negara 